\title{
Steroid-refractory chronic graft-versus-host disease: treatment options and patient management
}

\author{
Daniel Wolff $\mathbb{D}^{1 凶}{ }^{凶}$, Giancarlo Fatobene ${ }^{2,3}$, Vanderson Rocha ${ }^{2,3}$, Nicolaus Kröger (DD $^{4}$ and Mary E. Flowers ${ }^{5}$
}

(c) The Author(s) 2021

Chronic graft-versus-host disease (cGVHD) is one of the major causes of late mortality after allogenic hematopoietic stem cell transplantation. Moderate-to-severe CGVHD is associated with poor health-related quality of life and substantial disease burden. While corticosteroids with or without calcineurin inhibitors comprise the first-line treatment option, the prognosis for patients with steroid-refractory CGVHD (SR-cGVHD) remains poor. The mechanisms underlying steroid resistance are unclear, and there are no standard second-line treatment guidelines for patients with SR-cGVHD. In this review, we provide an overview on current treatment options of cGVHD and use a series of theoretical case studies to elucidate the rationale of choices of second-and third-line treatment options for patients with SR-cGVHD based on individual patient profiles.

Bone Marrow Transplantation (2021) 56:2079-2087; https://doi.org/10.1038/s41409-021-01389-5

\section{INTRODUCTION}

The use of allogenic hematopoietic stem cell transplant (allo$\mathrm{HSCT}$ ) for treatment of malignant and non-malignant conditions continues to increase annually due to significant improvement in early mortality [1], but moderate or severe chronic graft-versushost disease (cGVHD) remains a major limitation for broadening the allo-HSCT clinical application [2] with patients developing steroid-refractory cGVHD (SR-cGVHD) having a significantly increased morbidity and mortality [3]. SR-cGVHD has been defined as CGVHD progression while on prednisone at $\geq 1 \mathrm{mg} / \mathrm{kg} /$ day for 1-2 weeks, or stable cGVHD while on $\geq 0.5 \mathrm{mg} / \mathrm{kg} /$ day for 1-2 months, and additional patients remain steroid-dependent with repeated symptom flares during taper of corticosteroids below $0.25 \mathrm{mg} / \mathrm{kg} /$ day [4].

The National Institutes of Health $(\mathrm{NIH})$ consensus criteria define acute GVHD (aGVHD) and CGVHD based on a combination of clinical features and time of onset [5]. Approximately $30-70 \%$ of allo-HSCT recipients surviving at least 100 days post-transplant develop cGVHD [6]. Increasing rates have been reported in recent decades [7] due to several factors, including increased use of granulocyte colony-stimulating factor mobilized blood stem cells as the graft source, increased patient's age, and use of unrelated as well as HLA-mismatch donors with the previous aGVHD, further increasing risk $[8,9]$.

Unlike in aGVHD, the underlying pathogenesis of CGVHD is not well understood, but is thought to be complex and multifactorial, with involvement of $T$ and $B$ cells as well as innate responses, including the transition from inflammation to fibrosis involving fibroblasts and macrophages [10-12]. Decreased regulatory T cells $(\mathrm{CD} 4+\mathrm{CD} 25+)$ have been observed in CGVHD, which may increase the proliferation of type $1 \mathrm{~T}$ cells [13]. Increased levels of transforming growth factor- $\beta$ are observed in patients with cGVHD compared with healthy controls, although its role in disease pathogenesis has not been established $[14,15]$. Additionally, autoantibody production by host-reactive B cells and plasmablasts, fibrotic changes following type 2 donor responses, and thymic damage impairing immune-reconstitution contribute to the pathogenesis $[10,15]$. Figure 1 contains a summary of the pathophysiology of cGVHD including treatment options targeting specific pathways.

There is also an emerging understanding of the role of the gut microbiome on CGVHD presentation [16]. Loss of flora diversity following allo-HSCT has been associated with the development of aGVHD and CGVHD, as well as increased mortality risk [17]. However, the specific role of these intestinal changes in cGVHD has not been studied as thoroughly as in aGVHD.

Signs and symptoms of cGVHD can be stratified as diagnostic, distinctive, and those in common with aGVHD [5], but patients can also show manifestations of other immune-mediated disease such as Hashimoto's thyroiditis or glomerulonephritis ("other/associated" manifestations) [4]. Correct diagnosis is crucial for the treatment of CGVHD. Of note, a significant proportion of patients lack diagnostic signs of CGVHD and several case series showed that a relevant subgroup of patients being treated for CGVHD in the absence of histopathological confirmation had other diseases, not GVHD [18, 19]. Therefore, patients not responding to treatment for suspected cGVHD and lacking diagnostic symptoms, should be re-evaluated by histopathology $[20,21]$.

Clinical features may affect multiple organs or body areas, with varying presentation depending on the site involved $[6,10]$. The skin is most commonly affected, observed in up to 75\% of cGVHD cases; symptoms and signs include poikiloderma, lichen planus-

\footnotetext{
${ }^{1}$ Department of Internal Medicine III, University Hospital Regensburg, Regensburg, Germany. ${ }^{2}$ Hospital das Clinicas da Faculdade de Medicina da Universidade de São Paulo (HCFMUSP), São Paulo, Brazil. 'Vila Nova Star Hospital and IDOR, Rede D'Or, São Paulo, Brazil. ${ }^{4}$ Department of Stem Cell Transplantation, University Medical Center Hamburg, Hamburg, Germany. ${ }^{5}$ Clinical Research Division, Fred Hutchinson Cancer Research Center and Department of Medicine, University of Washington, Seattle, Seattle, WA, USA. email: daniel.wolff@ukr.de
} 


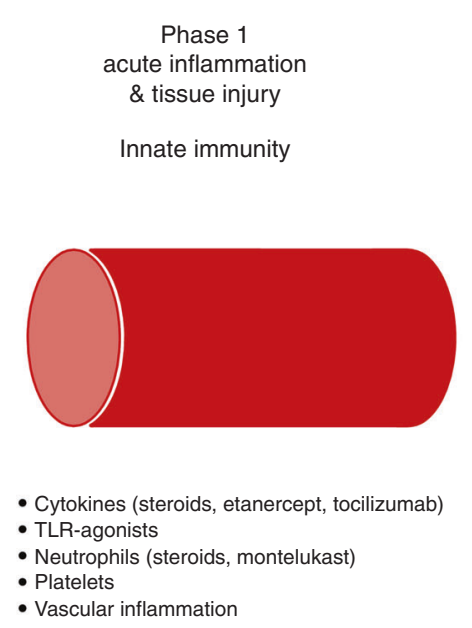

Phase 1

ute inflammation

nate immunity

- TLR-agonists

- Vascular inflammation
Adaptive immunity

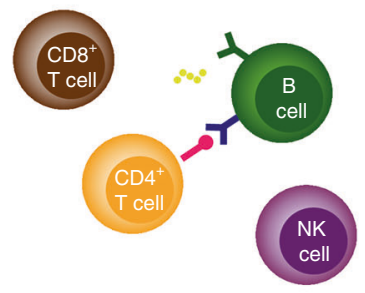

- Thymic injury \& dysfunction

- T cells (CNI, mTOR-Inh., MMF, ruxolitinib, baricitinib, cyclo., pentostatin, MTX, abatacept, alefacept, TNI)

- B cells (ibrutinib, MMF, rituximab, tocilizumab)

- Plasmablasts (proteosome inhibitors, imids)

- Antigen presenting cells (steroids, mTOR-inhibitors)

- Treg (IL-2, ECP, MSC) \& B reg cells
Phase 3

aberrant tissue repair

\& fibrosis

Innate \& adaptive

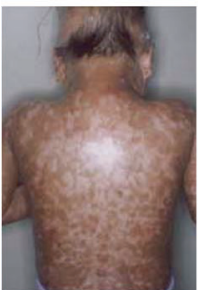

- TGF $\beta$ (pirfenidon, nintedanib)

- PDGF $\alpha$ (imatinib, nilotinib)

- Fibroblasts (lenabasum)

- TNF (etanercept)

- IL17 (belumosudil)

- Macrophages (axatilimab)

Legend: mTOR-Inh: mTOR-inhibitors (sirolimus; everolimus); imids: thalidomide, pomalidomide, proteosome-inhibitors: bortezomib, ixazomib; cyclo: cyclophosphamide,

listing of one target dose not exclude additional targets in specific drugs (i.e.: proteosome inhibitors target $\mathrm{T}$ \& $\mathrm{B}$ cells and plasma cells)

Fig. 1 Biologic phases of C-GVHD with agents added targeting specific pathways (modified version derived from Cooke 2017 [24]). CNI calcineurin inhibitors, cyclo. cyclophosphamide, ECP extracorporeal photopheresis, IL-2 interleukin-2, IL17 interleukin 17, imids immunomodulatory imide drugs, MMF mycophenolate mofetil, MSC mesenchymal stromal cells, $m T O R-I n h$. mechanistic target of rapamycin inhibitors, MTX methotrexate, PDGFa platelet-derived growth factor receptor alpha, TGF $\beta$ transforming growth factor $\beta$, TLR Toll-like receptor, TNFa tumor necrosis factor alpha, TNI total nodal irradiation. mTOR-Inh.: sirolimus, everolimus; imids: thalidomide, pomalidomide; proteosome inhibitors: bortezomib, ixazomib. It should be noted that listing of one target does not exclude additional targets in specific drugs (i.e. proteosome inhibitors target T cells, $B$ cells, and plasma cells).

like eruptions, sclerotic features, and depigmentation [5]. The presence and severity of organ-specific signs and symptoms (NIH score 0 to 3 ) contribute to the NIH global severity of cGVHD (mild, moderate, or severe) [5]. While overall severity has a significant impact on morbidity and mortality, additional risk factors for increased mortality consistently reported include direct progression from aGVHD to CGVHD, and platelets $<100 / \mathrm{nL}$ at time of diagnosis [22]. Moreover, certain organ involvement such as the lung and gastrointestinal tract, and hyperbilirubinemia are associated with a poor prognosis [23].

In addition to organ impairment caused by cGVHD, patients often have comorbidities associated with treatment, such as osteoporosis induced by corticosteroids [7]. Overall, cGVHD is associated with considerable patient burden and impacts healthrelated quality of life, depending on the clinical features experienced, and reduced health-related quality of life correlates with increased disease severity and lack of response to treatment $[24,25]$. Patients frequently report reduced functional capabilities [26], psychological distress [27], and negative mood [26]. Furthermore, CGVHD has been associated with diagnoses of disabilities including keratoconjunctivitis sicca, sclerosis, and reduced lung function $[28,29]$. Uninsured patients may also face a substantial financial burden from cGVHD due to high treatment costs [30].

Standard GVHD prophylaxis for HLA-matched transplants comprises a calcineurin inhibitor plus a short course of methotrexate or mycophenolate mofetil (MMF) with or without additional antithymocyte globulin (ATG) in transplants from unrelated donors; ATG has recently been also recommended for use in HLA-identical sibling transplantation [31]. The aim of these prophylactic treatments is to reduce the risk of aGVHD, one of the major risk factors for CGVHD which continue to manifest in approximately half of the patients [32]. Nevertheless, several approaches have resulted in decreased rates of cGVHD, including the use of ATG as part of GVHD prophylaxis [33-36] and posttransplant cyclophosphamide in combination with a calcineurin inhibitor (with or without MMF), even in the peripheral blood stem cell transplantation setting and naïve T-depleted grafts [37]. Post- transplant cyclophosphamide has also increased the number of haplo-identical donors without any increases in rates of cGVHD $[38,39]$. However, a significant percentage of patients will develop moderate-to-severe cGVHD [40, 41]. Early intervention can ameliorate symptoms and improve survival rates for patients who develop cGVHD [5]. Patients with mild cGVHD may only require treatment with local therapies such as topical steroids, depending on the organ or site affected and on the risk of relapse of the underlying disease [42]. The recommended first-line treatment for moderate or severe disease is systemic corticosteroids (prednisone) with or without a calcineurin inhibitor [3, 31, 42]. Overall, only $40-50 \%$ of patients respond adequately to first-line treatment, and over half become steroid-resistant or -dependent, requiring second-line treatment within 2 years due to suboptimal responses, loss of response, or unsuccessful steroid tapering $[3,6]$. Additionally, the long-term use of immunosuppressants, including steroids, has been associated with significant toxicity and increased risk of infection [10].

The mechanisms of steroid resistance in CGVHD are not well described [43], and prognosis remains poor for individuals with SR-cGVHD. Steroid resistance has been characterized in many inflammatory diseases such as asthma, chronic obstructive pulmonary disease, and rheumatoid arthritis [44]. To date, several underlying mechanisms have been identified for these conditions, including activation of mitogen-activated protein kinase, reduced histone deacetylase-2 expression, activation of transcription factor activator protein 1 , and increased P-glycoprotein-mediated drug efflux [44]. It is yet to be investigated whether any of these mechanisms play a role in GVHD. While we are not aware of any studies into the mechanisms of steroid resistance in CGVHD, murine models have been developed for aGVHD [43]. Despite the key role of $T$ cell responses in aGVHD, these models showed no significant association with donor T cell characteristics, inflammatory cytokine levels, or timing of steroid initiation [43], whereas increasing evidence underlines the role of myeloid cells and fibroblasts [45]. While steroid-resistant cGVHD, as defined by a lack of response to steroids, is challenging, a significant number of patients respond to a regimen of increased steroids. However, 
exacerbations of cGVHD are frequent when steroid withdrawal is attempted, resulting in significant long-term morbidity due to prolonged use of steroids. Research on the mechanisms of steroidrefractoriness and -dependence remains ongoing and will aid in developing treatments to overcome steroid resistance. Another clinical challenge in SR-cGVHD remains the non-reversibility of certain organ manifestations [24, 46], such as severe ocular involvement which rarely responds to immunosuppressive treatment, and deep cutaneous sclerosis showing a protracted response, if any [3]. The same applies for pulmonary manifestations, with stabilization of the condition regarded as a success, which impairs appraisal of the treatment efficacy [47].

There are no standard second-line treatments for patients with SR-cGVHD. While an increasing number of treatment options are becoming available, data are limited, and no consensus has been found on an optimal approach; these circumstances lead to a wide variation in individual clinical practice $[3,31,48]$. Numerous clinical trials have been performed to evaluate interventions [49], and results from retrospective and prospective studies often report high response rates, but are difficult to interpret due to variations in study design and populations treated [50]. Table 1 outlines some of the main second- and third-line treatment options currently available for SR-cGVHD. The choice of treatment for SRcGVHD is largely patient-specific and based on several factors, including clinical experience and published evidence, risk profile, disease history, comorbidities, individual tolerance to medication, and access to ongoing clinical trials [51]. Currently, ibrutinib, a Bruton's tyrosine kinase and interleukin-2-inducible $T$ cell kinase inhibitor, is the only FDA-approved therapy for SR-cGVHD. Ibrutinib targets both $B$ and T cells, making it an attractive option for manifestations that involve auto-antibody production.

In the second section of this review, we discuss three case studies of patients with SR-cGVHD from our clinics and suggest potential treatment options based on their individual profiles.

\section{CASE PRESENTATION \\ Patient 1}

Patient 1 is a 74-year-old male former smoker who received a peripheral blood HLA-mismatched graft from an unrelated female donor. He was initially treated for quiescent onset of moderate CGVHD (skin grade 2 , mouth grade 1 , and lung grade 1) starting 10 months after transplantation, with $1 \mathrm{mg} / \mathrm{kg} /$ day prednisone tapered to $0.25 \mathrm{mg} / \mathrm{kg} /$ day plus tacrolimus and fluticasone, azithromycin, and montelukast therapy. He then developed $a>15 \%$ decline in forced expiratory volume in 1 second $\left(\mathrm{FEV}_{1}\right)$ with steroid taper, $\mathrm{FEV}_{1}$ of $44 \%$, $\mathrm{FEV}_{1} /$ forced vital capacity of 0.62 (grade 2), moderate mouth symptoms with lichenoid features and ulceration (grade 2), and deep sclerotic features on lower limbs (grade 3 ). He has an active fungal lung infection and confirmed cytomegalovirus reactivation.

\section{Treatment options}

Patients with SR-cGVHD should ideally be enrolled in a clinical trial; however, this case would most likely not meet eligibility criteria due to the active fungal infection. Despite the greater efficacy of ruxolitinib than best available therapy in patients with SR-cGVHD [52], the patient's active fungal and viral infections cause some reluctance for use of ruxolitinib, ibrutinib, or MMF due to a further increase in risk for exacerbation of the ongoing infections. Given the severity of his baseline airway obstruction, the possibility of further bronchiolitis obliterans syndrome progression despite active fungal infection, and his poorly controlled CGVHD (affecting extrapulmonary sites), we would favor prompt initiation of extracorporeal photopheresis (ECP). ECP has been assessed in both steroid-dependent- and SR-cGVHD patients [53] and has demonstrated efficacy and safety in the treatment of bronchiolitis obliterans syndrome following HSCT and lung transplantation [54, 55]. It has also shown significant response rates in patients with sclerodermatous and mucosal GVHD in previous studies, including a randomized phase 2 trial $[53,56]$. ECP increases regulatory $T$ cells, with beneficial effects reported in patients with sclerotic SR-cGVHD [53]. ECP is associated with very low rates of infectious complications and has a steroid-sparing effect in cGVHD, which is particularly appropriate for this case $[53,55]$. Among the many different schedules reported for ECP delivery, we usually administer it twice weekly for the first month and then twice weekly every other week for 6 to 12 months. Once ECP is initiated, we also pursue steroid tapering as soon as possible, to reduce the impact on the treatment of his fungal infection and to avoid new cytomegalovirus reactivation episodes. To monitor lung response and guide steroid tapering or further therapy, we would order pulmonary function tests at least every 4 weeks during the first 3 months. We would consider ECP discontinuation only if GVHD progresses after at least 3 months of therapy.

\section{Patient 2}

Patient 2 is a 58-year-old male who received a reducedintensity peripheral HSCT graft from his HLA-identical sister and GVHD prophylaxis with cyclosporine (CSP) and MMF. He developed steroid-sensitive classic grade 2 aGVHD (skin grade 2 , gut grade 1) on day +53 and presented 18 months after transplantation with quiescent onset of high risk CGVHD, including elevated bilirubin $>3 \mathrm{mg} / \mathrm{dl}$ (grade 3 ) plus fasciitis affecting wrists, elbows, and shoulders, with moderate limitation in the photographic range of motion scale (P-ROM) of 16 (grade 2), while still receiving treatment with low-dose corticosteroids and sirolimus. Both episodes (aGVHD and CGVHD), which were initially treated with prednisone $1 \mathrm{mg} /$ $\mathrm{kg} /$ day, were complicated by latent steroid-psychosis requiring a rapid taper of steroids and combination treatment. The patient also experienced impaired renal function on CSP. At the time of cGVHD progression, immunoglobulins (lg) were above the normal range, with concurrent elevated $\operatorname{lgG} 1$ and $\lg \mathrm{G} 2$ deficiency. The patient also had an expanded CD19+ B cell count, normal CD4+ T cell counts, platelets $75 / \mathrm{nl}$, and granulocytes $1.5 / \mathrm{nl}$. Screening for liver-directed autoantibodies confirmed the presence of a significant titer of antinuclear and anti-smooth-muscle antibodies.

\section{Treatment options}

In this case, as the patient is thrombocytopenic, FDA-approved ibrutinib is not the most suitable option. While ibrutinib targets both $B$ cells and plasmablasts, it also interferes with platelet function, which may increase the risk of bleeding complications [57]. While MMF could be an option because of evidence from autoimmune hepatitis [58], the potential cytostatic effect of MMF may promote cytopenia already present. Additionally, while ECP could be beneficial for this patient, it requires time to reach a response and may be ineffective when given alone.

Therefore, we decided to treat the patient with a course of rituximab combined with ruxolitinib and to continue low-dose steroids because of prior intolerance. While ruxolitinib has been shown to be an effective immunosuppressive agent targeting $T$ cells and macrophages (both involved in CGVHD, including sclerosis), it also may indirectly target B cells, which are thought to be involved in this patient, by blocking follicular $T$ helper cells inducing new B cells [59]. The combination would permit the initial depletion of a significant proportion of autoreactive $B$ cells 


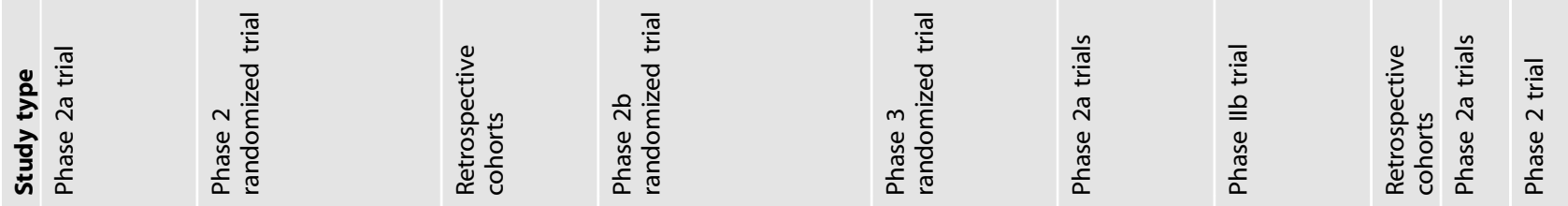

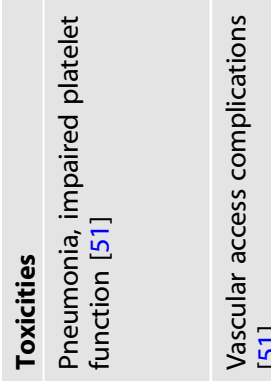
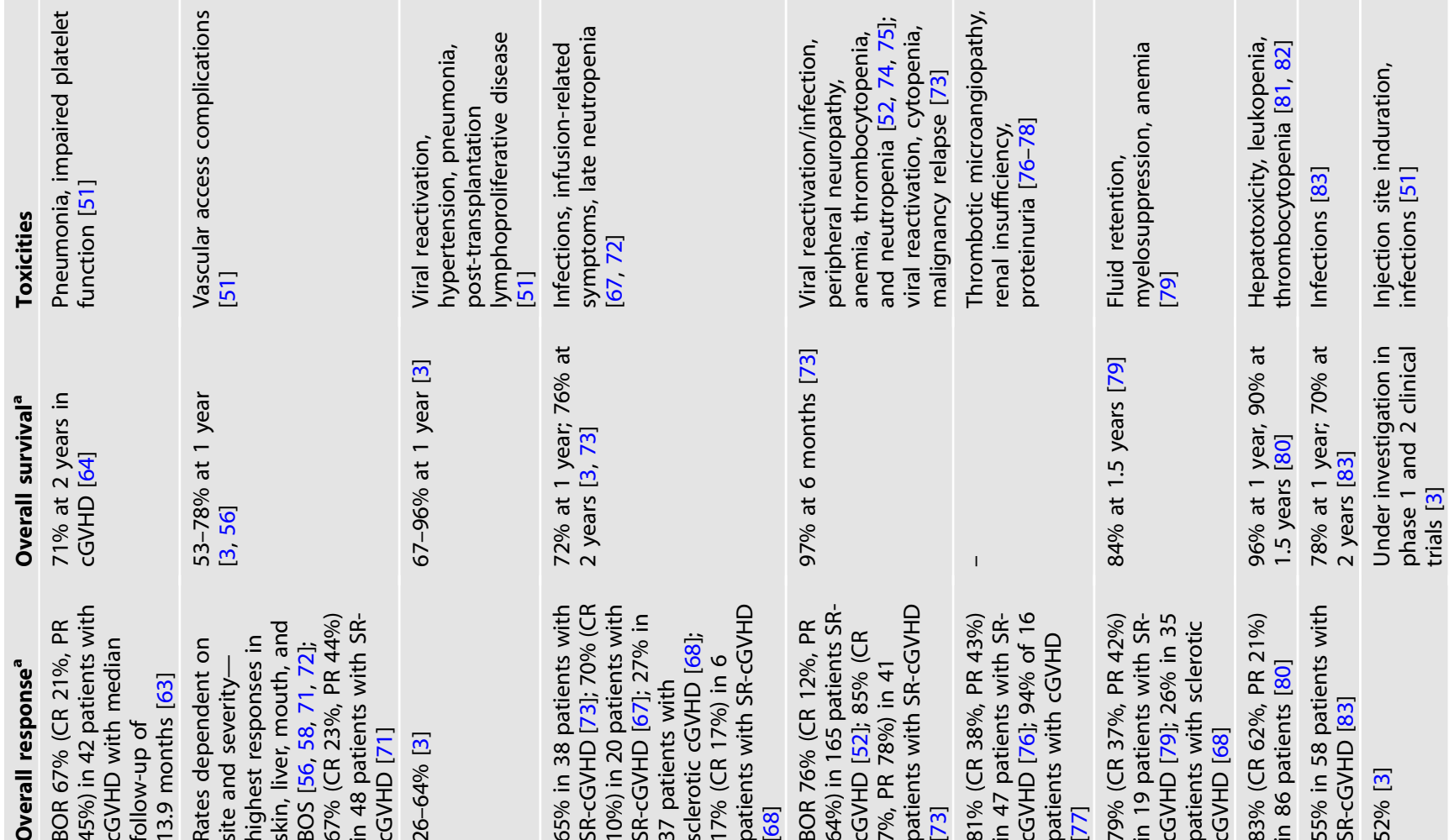

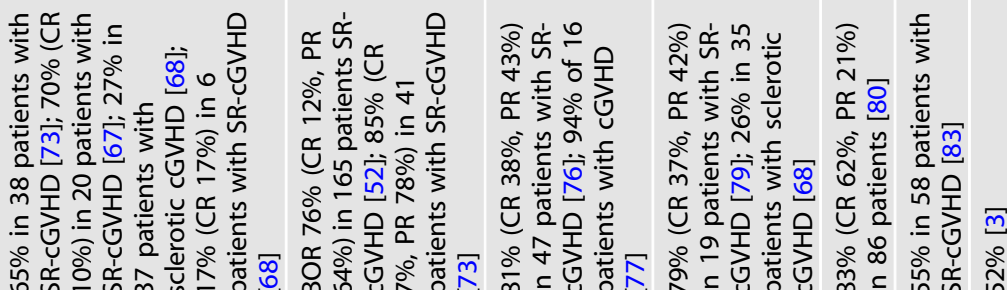

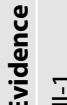

$\stackrel{\subsetneq}{\equiv}$
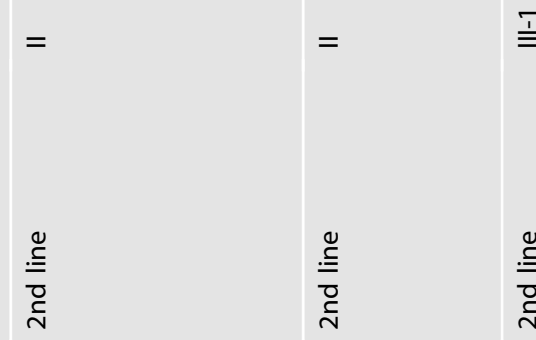

$\stackrel{\subsetneq}{\equiv}=$

$\stackrel{\subsetneq}{\equiv}=$ =

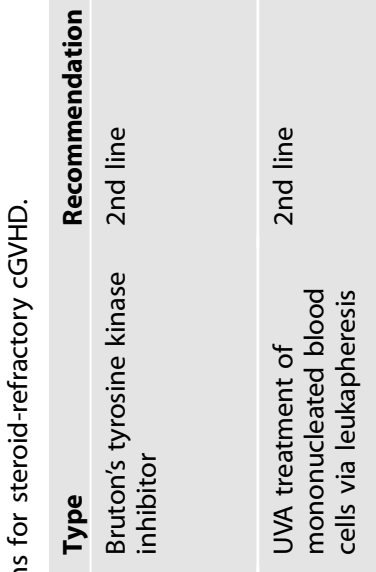

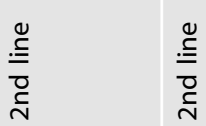

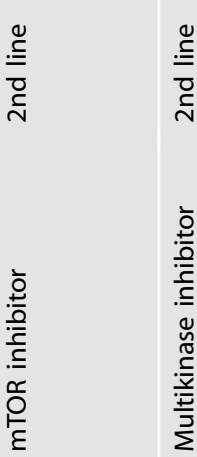

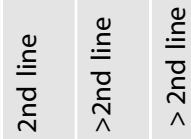

들

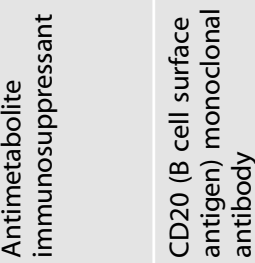

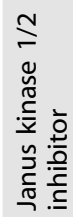
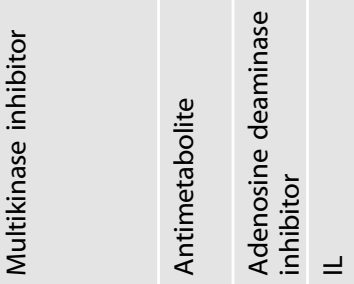

亭

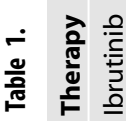
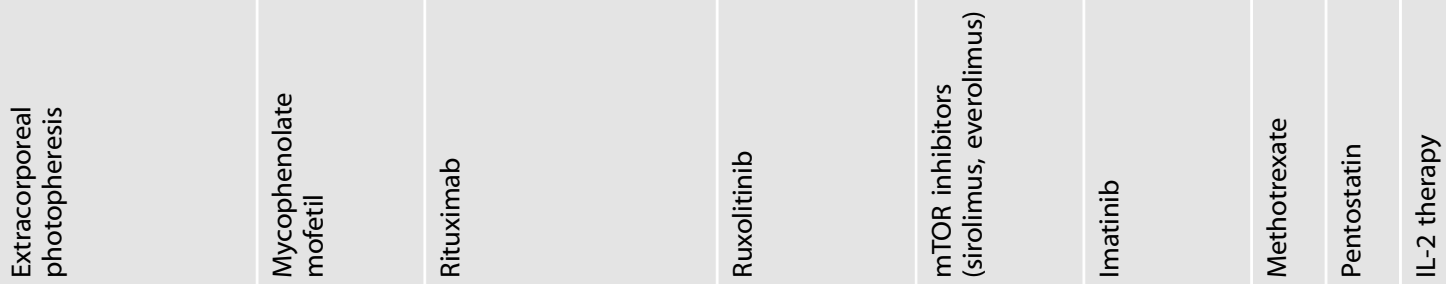


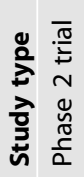

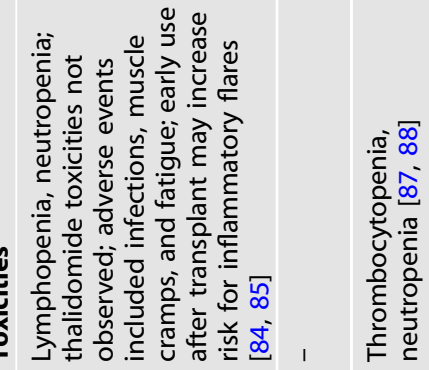

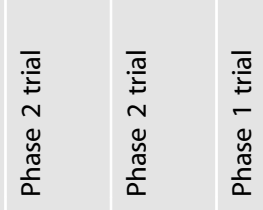

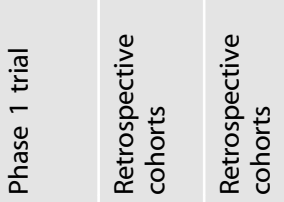

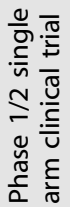
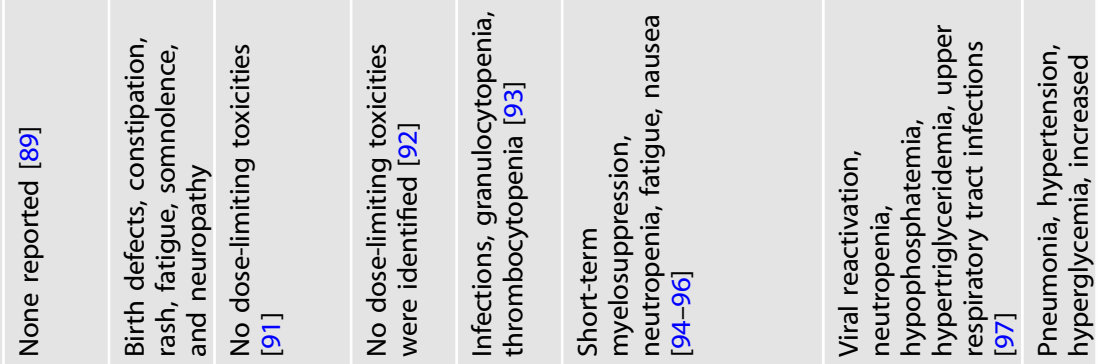
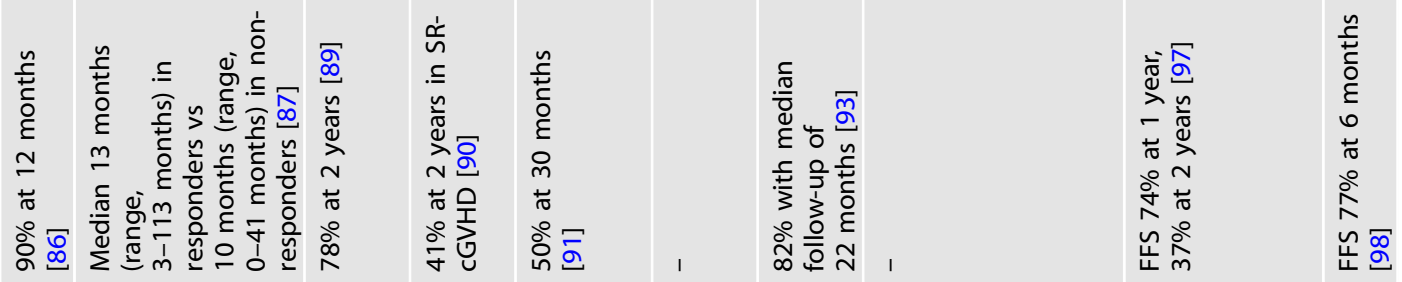

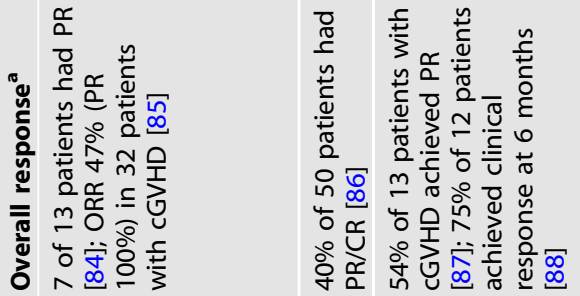

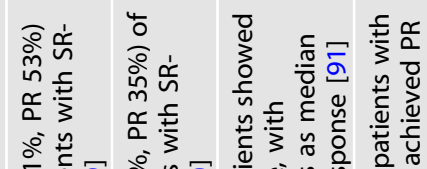

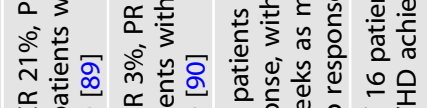

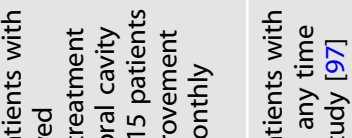

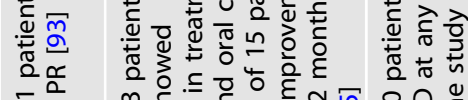

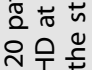
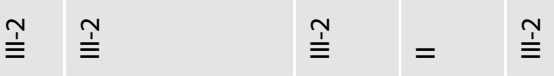

$\stackrel{\stackrel{N}{\equiv}}{\stackrel{\stackrel{N}{\equiv}}{\equiv}} \stackrel{\stackrel{N}{\equiv}}{ }$

$\stackrel{\text { }}{\equiv}$

$\stackrel{\varlimsup}{\equiv}$

离

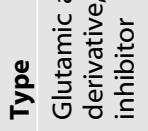

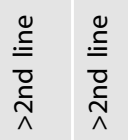

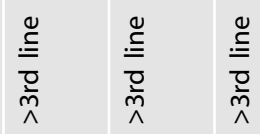

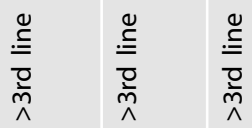

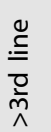

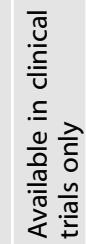

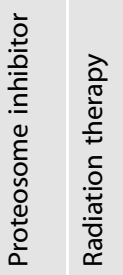

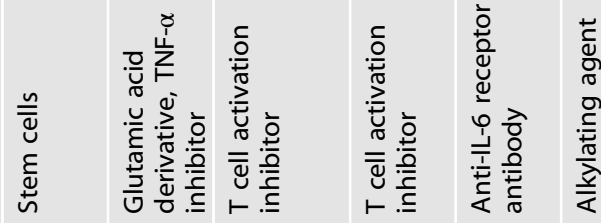

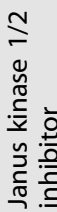

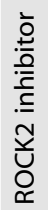

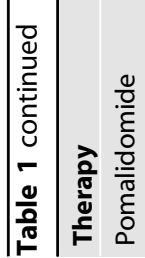

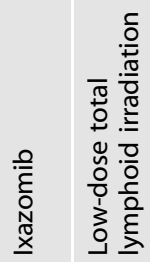

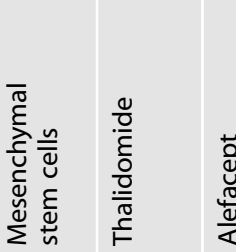

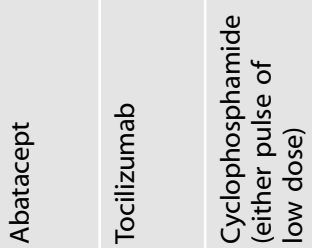

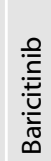

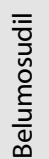


followed by a blockage of new "supply". Moreover, ruxolitinib has been associated with reactivation of prior seroconverted hepatitis $B$, indicating a suppressive effect on the humoral-mediated immune mechanism [60]. However, this strategy poses significant infectious risks, as both agents have been associated with infectious complications [61]. Therefore, proper infection prophylaxis (Pneumocystis jirovecii pneumonia, varicella-zoster virus) and continuing antibiotic prophylaxis is mandatory, and substitution of $\mathrm{lg}$ in the presence of bacterial infection complications to resolve the IgG2 deficiency is indicated. Ruxolitinib also requires monitoring of blood counts and liver enzymes, as the patient already has cytopenia and impaired liver function, predisposing him to side effects.

\section{Patient 3}

Patient 3 is a 66-year-old female who received a matched unrelated donor peripheral blood HSCT. She has active CGVHD with fibrotic and inflammatory manifestations despite 3 months of treatment with prednisone $0.5 \mathrm{mg} / \mathrm{kg} / \mathrm{day}$ and continued prophylactic CSP. Five months post-transplant, she presented with the following symptoms: morphea-like superficial sclerotic features in the skin plus lichen sclerosus (40\% body surface; grade 2); moderate mouth symptoms with lichenoid features (grade 2); vulvar lichen sclerosus-like features and mild discomfort (grade 1); and moderate dry eye symptoms with corneal keratinization but no vision impairment (grade 2). Preexisting comorbidities include type 2 diabetes, avascular necrosis, and neutropenia.

\section{Treatment options}

Due to lack of evidence to guide which therapy is superior for this patient specifically, we would first consider treatment in a clinical trial as an option for this case. We would replace CSP with another treatment, as CSP failed to control the progression and potentially impedes the emergence of regulatory $T$ cells, which are involved in the pathobiology of cGVHD [24]. Another consideration is to add a secondary therapy with a steroid-sparing effect, as this patient has diabetes and is at increased risk for prolonged systemic treatment including corticosteroids, because she received a peripheral blood HSCT instead of bone marrow transplant [62]. Finally, the treatment for this patient should be an agent that targets the pathobiology of sclerotic cGVHD phenotypes and has a reported beneficial effect in this clinical setting.

Several treatment options are available for this case. Ruxolitinib targets several signaling pathways involved in the pathobiology of cGVHD and has demonstrated superior efficacy than the best available therapy in patients with CGVHD in a recent phase 3 clinical trial [52]. Ruxolitinib may therefore be the preferred therapy option for this case, although the patient should be monitored for neutropenia and increased infection risk [52]. Alternatively, ibrutinib targets $T$ and $B$ cell signaling pathways and has reported responses in patients with sclerotic manifestations $[63,64]$. We would start ibrutinib at a dose of $280 \mathrm{mg}$ once daily plus anti-mold infection prophylaxis (i.e., voriconazole $200 \mathrm{mg}$ twice daily, or posaconazole $100 \mathrm{mg}$ twice daily), because of the concern of early invasive fungal infections [65]. Other treatment options include ECP or other treatments that increase regulatory $T$ cells, such as interleukin-2, which has also shown benefit in patients with sclerotic SR-cGVHD [66]. Rituximab, which has demonstrated initial high responses in retrospective studies (but lower responses in prospective studies) for sclerotic SR-cGVHD $[67,68]$ could also be considered if the treatments previously discussed are not suitable. Finally, MMF in combination with steroids could also be an option if other options are not feasible, 
but its efficacy for sclerotic cGVHD has not been tested prospectively.

A final important point for management of this case is to optimize supportive care [69], such as through the use of topical dexamethasone oral rinses together with oral nystatin to prevent/ treat superimposed yeast infection for oral manifestations, application of topical betamethasone for the vulva [69], and supportive ocular treatment including the use of eye lubricant, CSP ophthalmic emulsion, ocular punctal plugs, scleral lens, and other care [70].

\section{CONCLUSION}

In summary, these three patient cases illustrate multiple options available for patients with SR-cGVHD. While there is one FDAapproved treatment currently available, enrollment in ongoing clinical trials is also an important option for eligible patients whose treatment has failed on one or more previous therapies. In the absence of robust evidence of benefits for any one intervention, treatment choices should be based on physician experience, ease of use, need for monitoring, risk of toxicity, and potential worsening of pre-existing comorbidities.

\section{REFERENCES}

1. Passweg JR, Baldomero H, Chabannon C, Basak GW, Corbacioglu S, Duarte R, et al. European Society for Blood and Marrow Transplantation (EBMT). The EBMT activity survey on hematopoietic-cell transplantation and cellular therapy 2018: CAR-T's come into focus. Bone Marrow Transplant. 2020; e-pub ahead of print 17 Feb 2020. https://doi.org/10.1038/s41409-020-0826-4

2. Welniak LA, Blazar BR, Murphy WJ. Immunobiology of allogeneic hematopoietic stem cell transplantation. Annu Rev Immunol. 2007;25:139-70.

3. Flowers MED, Martin PJ. How we treat chronic graft-versus-host disease. Blood. 2015;125:606-15.

4. Schoemans HM, Lee SJ, Ferrara JL, Wolff D, Levine LE, Schultz KR, et al. EBMTNIH-CIBMTR Task Force position statement on standardized terminology \& guidance for graft-versus-host disease assessment. Bone Marrow Transplant. 2018;53:1401-15.

5. Jagasia MH, Greinix HT, Arora M, Williams KM, Wolff D, Cowen EW, et al. National Institutes of Health consensus development project on criteria for clinical trials in chronic graft-versus-host disease: I. The 2014 diagnosis and staging Working Group report. Biol Blood Marrow Transplant. 2015;21:389-401.e1.

6. Lee SJ, Vogelsang G, Flowers MED. Chronic graft-versus-host disease. Biol Blood Marrow Transplant. 2003;9:215-33.

7. Arai S, Arora M, Wang T, Spellman SR, He W, Couriel DR, et al. Increasing incidence of chronic graft-versus-host disease in allogeneic transplantation: a report from the Center for International Blood and Marrow Transplant Research. Biol Blood Marrow Transplant. 2015;21:266-74.

8. Barba P, Hilden P, Devlin SM, Maloy M, Dierov D, Nieves J, et al. Ex vivo CD34+ -selected T cell-depleted peripheral blood stem cell grafts for allogeneic hematopoietic stem cell transplantation in acute leukemia and myelodysplastic syndrome is associated with low incidence of acute and chronic graft-versus-host disease and high treatment response. Biol Blood Marrow Transplant. 2017;23:452-8.

9. Flowers MED, Inamoto Y, Carpenter PA, Lee SJ, Kiem H-P, Petersdorf EW, et al. Comparative analysis of risk factors for acute graft-versus-host disease and for chronic graft-versus-host disease according to National Institutes of Health consensus criteria. Blood. 2011;117:3214-9.

10. Ferrara JLM, Levine JE, Reddy P, Holler E. Graft-versus-host disease. Lancet. 2009;373:1550-61.

11. MacDonald KP, Blazar BR, Hill GR. Cytokine mediators of chronic graft-versus-host disease. J Clin Invest. 2017;127:2452-63.

12. Zhu $L$, Fu $X$, Chen $X$, Han $X$, Dong $P$. M2 macrophages induce EMT through the TGF- $\beta / S m a d 2$ signaling pathway. Cell Biol Int. 2017;41:960-8.

13. Chen $X$, Vodanovic-Jankovic $S$, Johnson B, Keller M, Komorowski R, Drobyski WR. Absence of regulatory $\mathrm{T}$-cell control of $\mathrm{TH} 1$ and $\mathrm{TH} 17$ cells is responsible for the autoimmune-mediated pathology in chronic graft-versus-host disease. Blood. 2007;110:3804-13.

14. Liem LM, Fibbe WE, van Houwelingen HC, Goulmy E. Serum transforming growth factor-beta1 levels in bone marrow transplant recipients correlate with blood cell counts and chronic graft-versus-host disease. Transplantation. 1999;67:59-65.

15. Martin PJ. Biology of chronic graft-versus-host disease: implications for a future therapeutic approach. Keio J Med. 2008;57:177-83.
16. Markey KA, Schluter J, Gomes ALC, Littmann ER, Pickard AJ, Taylor BP, et al. The microbe-derived short-chain fatty acids butyrate and propionate are associated with protection from chronic GVHD. Blood. 2020;136:130-6.

17. Peled JU, Gomes ALC, Devlin SM, Littmann ER, Taur Y, Sung AD, et al. Microbiota as predictor of mortality in allogeneic hematopoietic-cell transplantation. $\mathrm{N}$ Engl J Med. 2020;382:822-34.

18. Paun O, Phillips T, Fu P, Novoa RA, Honda KS, Lu KQ, et al. Cutaneous complications in hematopoietic cell transplant recipients: impact of biopsy on patient management. Biol Blood Marrow Transplant. 2013;19:1204-9.

19. Chahal P, Levy C, Litzow MR, Lindor KD. Utility of liver biopsy in bone marrow transplant patients. J Gastroenterol Hepatol. 2008;23:222-5.

20. Hillen U, Häusermann $P$, Massi D, Janin A, Wolff D, Lawitschka A, et al. Consensus on performing skin biopsies, laboratory workup, evaluation of tissue samples and reporting of the results in patients with suspected cutaneous graft-versus-host disease. J Eur Acad Dermatol Venereol. 2015;29:948-54.

21. Stift J, Baba HA, Huber E, Federmann B, Fischer H-P, Schmitt-Graeff A, et al. Consensus on the histopathological evaluation of liver biopsies from patients following allogeneic hematopoietic cell transplantation. Virchows Arch. 2014;464:175-90.

22. Kuzmina Z, Eder S, Böhm A, Pernicka E, Vormittag L, Kalhs $P$, et al. Significantly worse survival of patients with NIH-defined chronic graft-versus-host disease and thrombocytopenia or progressive onset type: results of a prospective study. Leukemia. 2012;26:746-56.

23. Grube M, Holler E, Weber D, Holler B, Herr W, Wolff D. Risk factors and outcome of chronic graft-versus-host disease after allogeneic stem cell transplantation-results from a single-center observational study. Biol Blood Marrow Transplant. 2016;22:1781-91.

24. Cooke KR, Luznik L, Sarantopoulos S, Hakim FT, Jagasia M, Fowler DH, et al. The biology of chronic graft-versus-host disease: a task force report from the National Institutes of Health consensus development project on criteria for clinical trials in chronic graft-versus-host disease. Biol Blood Marrow Transplant. 2017;23:211-34.

25. Herzberg PY, Heussner P, Mumm FHA, Horak M, Hilgendorf I, von Harsdorf $S$, et al. Validation of the human activity profile questionnaire in patients after allogeneic hematopoietic stem cell transplantation. Biol Blood Marrow Transplant. 2010;16:1707-17.

26. Jacobs JM, Fishman S, Sommer R, Sereno I, Fenech A, Jankowski AL, et al. Coping and modifiable psychosocial factors are associated with mood and quality of life in patients with chronic graft-versus-host disease. Biol Blood Marrow Transplant. 2019;25:2234-42.

27. El-Jawahri A, Pidala J, Khera N, Wood WA, Arora M, Carpenter PA, et al. Impact of psychological distress on quality of life, functional status, and survival in patients with chronic graft-versus-host disease. Biol Blood Marrow Transplant. 2018;24:2285-92.

28. Fatobene G, Storer BE, Salit RB, Lee SJ, Martin PJ, Cheng G-S, et al. Disability related to chronic graft-versus-host disease after alternative donor hematopoietic cell transplantation. Haematologica 2019;104:835-43.

29. Hamilton BK, Storer BE, Wood WA, Pidala JA, Cutler CS, Martin PJ, et al. Disability related to chronic graft-versus-host disease. Biol Blood Marrow Transplant. 2019;26:772-7.

30. Khera N, Hamilton BK, Pidala JA, Wood WA, Wu V, Voutsinas J, et al. Employment, insurance, and financial experiences of patients with chronic graft-versus-host disease in North America. Biol Blood Marrow Transplant. 2019;25:599-605.

31. Penack O, Marchetti M, Ruutu T, Aljurf M, Bacigalupo A, Bonifazi F, et al. Prophylaxis and management of graft versus host disease after stem-cell transplantation for haematological malignancies: updated consensus recommendations of the European Society for Blood and Marrow Transplantation. Lancet Haematol. 2020;7: e157-67.

32. Williams KM, Inamoto $Y, \operatorname{Im} A$, Hamilton B, Koreth J, Arora $M$, et al. National Institutes of Health consensus development project on criteria for clinical trials in chronic graft-versus-host disease: I. The 2020 etiology and prevention Working Group Report. Transplant Cell Ther. 2021; e-pub ahead of print 2 Mar 2021. https://doi.org/10.1016/j.jtct.2021.02.035.

33. Kröger N, Solano C, Wolschke C, Bandini G, Patriarca F, Pini M, et al. Antilymphocyte globulin for prevention of chronic graft-versus-host disease. $\mathrm{N}$ Engl J Med. 2016;374:43-53.

34. Walker I, Panzarella T, Couban S, Couture F, Devins G, Elemary M, et al. Pretreatment with anti-thymocyte globulin versus no anti-thymocyte globulin in patients with haematological malignancies undergoing haemopoietic cell transplantation from unrelated donors: a randomised, controlled, open-label, phase 3, multicentre trial. Lancet Oncol. 2016;17:164-73.

35. Soiffer RJ, Kim HT, McGuirk J, Horwitz ME, Johnston L, Patnaik MM, et al. Prospective, randomized, double-blind, phase III clinical trial of anti-T-lymphocyte globulin to assess impact on chronic graft-versus-host disease-free survival in patients undergoing HLA-matched unrelated myeloablative hematopoietic cell transplantation. J Clin Oncol. 2017;35:4003-11. 
36. Chang Y-J, Wu D-P, Lai Y-R, Liu Q-F, Sun Y-Q, Hu J, et al. Antithymocyte globulin for matched sibling donor transplantation in patients with hematologic malignancies: a multicenter, open-label, randomized controlled study. J Clin Oncol. 2020;38:3367-76.

37. Mielcarek M, Furlong T, O'Donnell PV, Storer BE, McCune JS, Storb R, et al. Posttransplantation cyclophosphamide for prevention of graft-versus-host disease after HLA-matched mobilized blood cell transplantation. Blood. 2016;127:1502-8.

38. Ciurea SO, Zhang M-J, Bacigalupo AA, Bashey A, Appelbaum FR, Aljitawi OS, et al. Haploidentical transplant with posttransplant cyclophosphamide vs matched unrelated donor transplant for acute myeloid leukemia. Blood. 2015;126:1033-40.

39. Kanate AS, Mussetti A, Kharfan-Dabaja MA, Ahn KW, DiGilio A, Beitinjaneh A, et al. Reduced-intensity transplantation for lymphomas using haploidentical related donors vs HLA-matched unrelated donors. Blood. 2016;127:938-47.

40. Bashey A, Zhang M-J, McCurdy SR, St Martin A, Argall T, Anasetti C, et al. Mobilized peripheral blood stem cells versus unstimulated bone marrow as a graft source for T-cell-replete haploidentical donor transplantation using posttransplant cyclophosphamide. J Clin Oncol. 2017;35:3002-9.

41. Lee SJ, Logan B, Westervelt P, Cutler C, Woolfrey A, Khan SP, et al. Comparison of patient-reported outcomes in 5-year survivors who received bone marrow vs peripheral blood unrelated donor transplantation: long-term follow-up of a randomized clinical trial. JAMA Oncol. 2016;2:1583-9.

42. Dignan FL, Amrolia P, Clark A, Cornish J, Jackson G, Mahendra P, et al. Diagnosis and management of chronic graft-versus-host disease. $\mathrm{Br} J$ Haematol. 2012;158:46-61.

43. Toubai T, Rossi C, Tawara I, Liu C, Zajac C, Oravecz-Wilson K, et al. Murine models of steroid refractory graft-versus-host disease. Sci Rep. 2018;8:12475.

44. Barnes PJ, Adcock IM. Glucocorticoid resistance in inflammatory diseases. Lancet. 2009;373:1905-17.

45. MacDonald KPA, Hill GR, Blazar BR. Chronic graft-versus-host disease: biological insights from preclinical and clinical studies. Blood. 2017;129:13-21.

46. Alexander KA, Flynn R, Lineburg KE, Kuns RD, Teal BE, Olver SD, et al. CSF-1dependant donor-derived macrophages mediate chronic graft-versus-host disease. J Clin Invest. 2014;124:4266-80.

47. Cheng G-S, Storer B, Chien JW, Jagasia M, Hubbard JJ, Burns L, et al. Lung function trajectory in bronchiolitis obliterans syndrome after allogeneic hematopoietic cell transplant. Ann Am Thorac Soc. 2016;13:1932-9.

48. Wolff D, Hilgendorf I, Wagner-Drouet E, Jedlickova Z, Ayuk F, Zeiser R, et al. Changes in immunosuppressive treatment of chronic graft-versus-host disease: comparison of 2 surveys within allogeneic hematopoietic stem cell transplant centers in Germany, Austria, and Switzerland. Biol Blood Marrow Transplant. 2019;25:1450-5.

49. Wolff D, Schleuning M, von Harsdorf S, Bacher U, Gerbitz A, Stadler M, et al. Consensus conference on clinical practice in chronic GVHD: second-line treatment of chronic graft-versus-host disease. Biol Blood Marrow Transplant. 2011;17:1-17.

50. Martin PJ, Inamoto Y, Carpenter PA, Lee SJ, Flowers MED. Treatment of chronic graft-versus-host disease: past, present and future. Korean J Hematol. 2011;46:153-63.

51. Sarantopoulos $S$, Cardones AR, Sullivan KM. How I treat refractory chronic graftversus-host disease. Blood. 2019;133:1191-200.

52. Zeiser R, Polverelli N, Ram R, Hashmi SK, Chakraverty R, Flowers MED, et al. Ruxolitinib (RUX) vs best available therapy (BAT) in patients with steroid-refractory/ steroid-dependent chronic graft-vs-host disease (cGVHD): primary findings from the phase 3, randomized REACH3 Study. Blood. 2020;136(Supplement 1):22-24.

53. Flowers MED, Apperley JF, van Besien K, Elmaagacli A, Grigg A, Reddy V, et al. A multicenter prospective phase 2 randomized study of extracorporeal photopheresis for treatment of chronic graft-versus-host disease. Blood. 2008;112:2667-74.

54. Jaksch $P$, Scheed $A$, Keplinger $M$, Ernst $M-B$, Dani T, Just $U$, et al. A prospective interventional study on the use of extracorporeal photopheresis in patients with bronchiolitis obliterans syndrome after lung transplantation. J Heart Lung Transplant. 2012;31:950-7.

55. Lucid CE, Savani BN, Engelhardt BG, Shah P, Clifton C, Greenhut SL, et al. Extracorporeal photopheresis in patients with refractory bronchiolitis obliterans developing after allo-SCT. Bone Marrow Transplant. 2011:46:426-9.

56. Couriel DR, Hosing C, Saliba R, Shpall EJ, Anderlini P, Rhodes B, et al. Extracorporeal photochemotherapy for the treatment of steroid-resistant chronic GVHD. Blood. 2006;107:3074-80.

57. Shatzel JJ, Olson SR, Tao DL, McCarty OJT, Danilov AV, DeLoughery TG. Ibrutinibassociated bleeding: pathogenesis, management and risk reduction strategies. J Thromb Haemost. 2017;15:835-47.

58. Santiago P, Schwartz I, Tamariz L, Levy C. Systematic review with meta-analysis: mycophenolate mofetil as a second-line therapy for autoimmune hepatitis. Aliment Pharm Ther. 2019;49:830-9.
59. Ricard L, Jachiet V, Malard F, Ye Y, Stocker N, Rivière S, et al. Circulating follicular helper $\mathrm{T}$ cells are increased in systemic sclerosis and promote plasmablast differentiation through the IL-21 pathway which can be inhibited by ruxolitinib. Ann Rheum Dis. 2019;78:539-50.

60. Caocci G, Murgia F, Podda L, Solinas A, Atzeni S, La, Nasa G. Reactivation of hepatitis $B$ virus infection following ruxolitinib treatment in a patient with myelofibrosis. Leukemia. 2014;28:225-7.

61. Abedin S, McKenna E, Chhabra S, Pasquini M, Shah NN, Jerkins J, et al. Efficacy, toxicity, and infectious complications in ruxolitinib-treated patients with corticosteroid-refractory graft-versus-host disease after hematopoietic cell transplantation. Biol Blood Marrow Transplant. 2019;25:1689-94.

62. Flowers MED, Parker PM, Johnston LJ, Matos AVB, Storer B, Bensinger WI, et al. Comparison of chronic graft-versus-host disease after transplantation of peripheral blood stem cells versus bone marrow in allogeneic recipients: long-term follow-up of a randomized trial. Blood. 2002;100:415-9.

63. Miklos D, Cutler CS, Arora M, Waller EK, Jagasia M, Pusic I, et al. Ibrutinib for chronic graft-versus-host disease after failure of prior therapy. Blood. 2017;130:2243-50

64. Waller EK, Miklos D, Cutler C, Arora M, Jagasia MH, Pusic I, et al. Ibrutinib for chronic graft-versus-host disease after failure of prior therapy: 1-year update of a phase 1b/2 study. Biol Blood Marrow Transplant. 2019;25:2002-7.

65. Ghez D, Calleja A, Protin C, Baron M, Ledoux M-P, Damaj G, et al. French Innovative Leukemia Organization (FILO) CLL group. Early-onset invasive aspergillosis and other fungal infections in patients treated with ibrutinib. Blood. 2018;131:1955-9.

66. Koreth J, Kim HT, Jones KT, Lange PB, Reynolds CG, Chammas MJ, et al. Efficacy, durability, and response predictors of low-dose interleukin-2 therapy for chronic graft-versus-host disease. Blood. 2016;128:130-7.

67. Cutler C, Miklos D, Kim HT, Treister N, Woo S-B, Bienfange D, et al. Rituximab for steroid-refractory chronic graft-versus-host disease. Blood. 2006;108:756-62.

68. Arai S, Pidala J, Pusic I, Chai X, Jaglowski S, Khera N, et al. A randomized phase II crossover study of imatinib or rituximab for cutaneous sclerosis after hematopoietic cell transplantation. Clin Cancer Res. 2016;22:319-27.

69. Couriel D, Carpenter PA, Cutler C, Bolaños-Meade J, Treister NS, Gea-Banacloche J, et al. Ancillary therapy and supportive care of chronic graft-versus-host disease: national institutes of health consensus development project on criteria for clinical trials in chronic graft-versus-host disease: V. ancillary therapy and supportive care working group report. Biol Blood Marrow Transplant. 2006;12:375-96.

70. Inamoto Y, Valdés-Sanz N, Ogawa Y, Alves M, Berchicci L, Galvin J, et al. Ocular graft-versus-host disease after hematopoietic cell transplantation: expert review from the late effects and quality of life working committee of the Center for International Blood and Marrow Transplant Research and Transplant Complications Working Party of the European Society of Blood and Marrow Transplantation. Biol Blood Marrow Transplant. 2019;25:e46-54.

71. Oarbeascoa G, Lozano ML, Guerra LM, Amunarriz C, Saavedra CA, Garcia-Gala JM, et al. Retrospective multicenter study of extracorporeal photopheresis in steroidrefractory acute and chronic graft-versus-host disease. Biol Blood Marrow Transplant. 2020;26:651-8.

72. Zaja F, Bacigalupo A, Patriarca F, Stanzani M, Van Lint MT, Fili C, et al. Treatment of refractory chronic GVHD with rituximab: a GITMO study. Bone Marrow Transplant. 2007;40:273-7.

73. Zeiser R, Burchert A, Lengerke C, Verbeek M, Maas-Bauer K, Metzelder SK, et al. Ruxolitinib in corticosteroid-refractory graft-versus-host disease after allogeneic stem cell transplantation: a multicenter survey. Leukemia. 2015;29:2062-8.

74. Jagasia MH, Haris A, Schroeder MA, Shah NN, Chen Y-B, Dawkins F, et al. Ruxolitinib in combination with corticosteroids for the treatment of steroid-refractory acute graft-vs-host disease: results from the phase 2 REACH1 trial. Biol Blood Marrow Transplant. 2019;25:Supp S52.

75. Jagasia M, Perales M-A, Schroeder MA, Ali H, Shah NN, Chen Y-B, et al. Ruxolitinib for the treatment of steroid-refractory acute GVHD (REACH1): a multicenter, open-label phase 2 trial. Blood.2020;135:1739-49.

76. Jurado $M$, Vallejo $C$, Pérez-Simón JA, Brunet S, Ferra C, Balsalobre P, et al. Sirolimus as part of immunosuppressive therapy for refractory chronic graft-versushost disease. Biol Blood Marrow Transplant. 2007;13:701-6.

77. Johnston $\sqcup$, Brown J, Shizuru JA, Stockerl-Goldstein KE, Stuart MJ, Blume KG, et al. Rapamycin (sirolimus) for treatment of chronic graft-versus-host disease. Biol Blood Marrow Transplant. 2005;11:47-55.

78. Mielke S, Lutz M, Schmidhuber J, Kapp M, Ditz D, Ammer J, et al. Salvage therapy with everolimus reduces the severity of treatment-refractory chronic GVHD without impairing disease control: a dual center retrospective analysis. Bone Marrow Transplant. 2014;49:1412-8.

79. Olivieri A, Locatelli F, Zecca M, Sanna A, Cimminiello M, Raimondi R, et al. Imatinib for refractory chronic graft-versus-host disease with fibrotic features. Blood. 2009;114:709-18. 
80. Wang $\mathrm{Y}, \mathrm{Xu}$ L-P, Liu D-H, Chen $\mathrm{H}$, Chen $\mathrm{Y}-\mathrm{H}, \mathrm{Han} \mathrm{W}$, et al. First-line therapy for chronic graft-versus-host disease that includes low-dose methotrexate is associated with a high response rate. Biol Blood Marrow Transplant. 2009;15:505-11.

81. Giaccone L, Martin P, Carpenter P, Moravec C, Hooper H, Funke VAM, et al. Safety and potential efficacy of low-dose methotrexate for treatment of chronic graftversus-host disease. Bone Marrow Transplant. 2005;36:337-41.

82. Huang X-J, Jiang Q, Chen H, Xu L, Liu D, Chen Y, et al. Low-dose methotrexate for the treatment of graft-versus-host disease after allogeneic hematopoietic stem cell transplantation. Bone Marrow Transplant. 2005;36:343-8.

83. Jacobsohn DA, Chen AR, Zahurak M, Piantadosi S, Anders V, Bolaños-Meade J, et al. Phase II study of pentostatin in patients with corticosteroid-refractory chronic graft-versus-host disease. J Clin Oncol. 2007;25:4255-61.

84. Pusic I, Rettig MP, DiPersio JF, Bauer S, McFarland K, Gale RP, et al. Phase-1/2 study of pomalidomide in chronic GvHD. Bone Marrow Transplant. 2016;51:612-4.

85. Curtis LM, Venzon D, Hakim FT, Cowen EW, Hsu J, Masuch L, et al. Final results of a randomized phase 2 trial evaluating lower-dose versus higher-dose pomalidomide as therapy for corticosteroid-refractory chronic Gvhd. Blood. 2016;128:507.

86. Pidala J, Bhatt VR, Hamilton B, Pusic I, Wood WA, Onstad L, et al. Ixazomib for treatment of refractory chronic graft-versus-host disease: a chronic GVHD consortium phase II trial. Biol Blood Marrow Transplant. 2020;26:1612-9.

87. Hautmann AH, Wolff D, Hilgendorf I, Fehn U, Edinger M, Hoffmann P, et al. Total nodal irradiation in patients with severe treatment-refractory chronic graftversus-host disease after allogeneic stem cell transplantation: response rates and immunomodulatory effects. Radiother Oncol. 2015;116:287-93.

88. Peyraga G, Lizee T, Gustin P, Clement-Colmou K, Di Bartolo C, Supiot S, et al. Treatment of cutaneous and/or soft tissue manifestations of corticosteroids refractory chronic graft versus host disease (cGVHD) by a total nodal irradiation (TNI). Clin Transplant. 2017;31:e12923.

89. Weng JY, Du X, Geng SX, Peng YW, Wang Z, Lu ZS, et al. Mesenchymal stem cell as salvage treatment for refractory chronic GVHD. Bone Marrow Transplant. 2010;45:1732-40.

90. Browne PV, Weisdorf DJ, DeFor T, Miller WJ, Davies SM, Filipovich A, et al. Response to thalidomide therapy in refractory chronic graft-versus-host disease. Bone Marrow Transplant. 2000;26:865-9.

91. Shapira MY, Abdul-Hai A, Resnick IB, Bitan M, Tsirigotis P, Aker M, et al. Alefacept treatment for refractory chronic extensive GVHD. Bone Marrow Transplant. 2009;43:339-43.

92. Nahas MR, Soiffer RJ, Kim HT, Alyea EP 3rd, Arnason J, Joyce R, et al. Phase 1 clinical trial evaluating abatacept in patients with steroid-refractory chronic graftversus-host disease. Blood. 2018;131:2836-45.

93. Kattner A-S, Holler E, Holler B, Klobuch S, Weber D, Martinovic D, et al. IL6receptor antibody tocilizumab as salvage therapy in severe chronic graft-versushost disease after allogeneic hematopoietic stem cell transplantation: a retrospective analysis. Ann Hematol. 2020;99:847-53.

94. Mayer J, Krejcí M, Doubek M, Pospísil Z, Brychtová Y, Tomíska M, et al. Pulse cyclophosphamide for corticosteroid-refractory graft-versus-host disease. Bone Marrow Transplant. 2005;35:699-705.

95. Chao NJ, Foster YG, Rowe K, Shah A, Cardones AR. Pulse cyclophosphamide for steroid-refractory chronic graft-versus-host disease. Biol Blood Marrow Transplant. 2016;22:S393-5.

96. Fante MA, Holler B, Weber D, Angstwurm K, Bergler T, Holler E, et al. Cyclophosphamide for salvage therapy of chronic graft-versus-host disease: a retrospective analysis. Ann Hematol. 2020;99:2181-90.

97. Holtzman NG, Im A, Ostojic A, Curtis LM, Parsons-Wandell L, Nashed J, et al. Efficacy and safety of baricitinib in refractory chronic graft-versus-host disease (cGVHD): preliminary analysis results of a phase $1 / 2$ study. Abstract 357 . Blood. 2020;136(Supplement 1):1.
98. Cutler C, Lee SJ, Arai S, Rotta M, Zoghi B, Ramakrishnan A, et al. Belumosudil for chronic graft-versus-host disease (cGVHD) after 2 or more prior lines of therapy: the Rockstar Study. Abstract 353. Blood. 2020;136(Supplement 1):45-6.

99. Arora M, Jagasia M, Di Stasi A, Meyers ML, Quaranto C, Schmitt S, et al. Phase 1 study of axatilimab (SNDX-6352), a CSF-1R humanized antibody, for chronic graft-versus-host disease after 2 or more lines of systemic treatment. Abstract 358. Blood. 2020;136(Supplement 1):1-2.

\section{ACKNOWLEDGEMENTS}

This work was supported by Novartis AG. The authors would like to thank Keisha Peters, MSc, and James Matthews, PhD, of Excerpta Medica, for editorial assistance in the preparation of this manuscript, supported by Novartis AG.

\section{FUNDING}

Open Access funding enabled and organized by Projekt DEAL.

\section{COMPETING INTERESTS}

D.W. has received honoraria from MACO, Mallinckrodt, Neovii Pharmaceuticals, Novartis AG, and Takeda Pharmaceutical Company Limited. G.F. has an advisory role and has served on speakers' bureaus for Janssen Global Services LLC. N.K. has received research support from Celgene, Novartis AG and RIEMSER Pharma GmbH; speaker honoraria from Bristol-Myers Squibb Company, Celgene Corporation, Gilead Sciences Inc., Janssen Global Services LLC, Kite, Neovii Pharmaceuticals, Novartis AG, and Sanofi. MEF has received research support from Incyte and Pharmacyclics LLC including AbbVie Inc.; speaker honoraria from Astellas Pharma US, Inc., Janssen Global Services LLC, and Mallinckrodt; and served as a consultant for CSL Behring Fresenius Kabi AG, and Pharmacyclics LLC. V.R. has no conflict of interest to report.

\section{ADDITIONAL INFORMATION}

Correspondence and requests for materials should be addressed to D.W.

Reprints and permission information is available at http://www.nature.com/ reprints

Publisher's note Springer Nature remains neutral with regard to jurisdictional claims in published maps and institutional affiliations.

ppen Access This article is licensed under a Creative Commons Attribution 4.0 International License, which permits use, sharing, adaptation, distribution and reproduction in any medium or format, as long as you give appropriate credit to the original author(s) and the source, provide a link to the Creative Commons license, and indicate if changes were made. The images or other third party material in this article are included in the article's Creative Commons license, unless indicated otherwise in a credit line to the material. If material is not included in the article's Creative Commons license and your intended use is not permitted by statutory regulation or exceeds the permitted use, you will need to obtain permission directly from the copyright holder. To view a copy of this license, visit http://creativecommons. org/licenses/by/4.0/.

(c) The Author(s) 2021 